\title{
HUKUM MENDIRIKAN PARTAI POLITIK PERSPEKTIF ISLAM: REFLEKSI ISLAM POLITIK KLASIK DAN MODERN
}

\author{
Amin Heri Susanto \\ Universitas Brawijaya \\ Email: aminovee2000@ub.ac.id
}

\begin{abstract}
The law of establishment political parties is an interesting discussion, this article explain with the data to analyze based in the history of Islam by identifying groups (hizb) who struggled the leadership for the their articulation rights, they were like Khawarij, Mu'tazilah and Shi'ite are identified as a reflection of Classical Political Islam. The reflection of Modern Political Islam is marked by an aggregation of contemporary needs that cannot be denied the necessity for the establishment of political parties by looking issues in Egypt and Indonesia in the early era of independence. The difference of views among scholars and ijma 'ulama are determining factors conclusion to judge the law of establishing party to Islamic perspective.
\end{abstract}

Keyword: Political Parties, Classical Political Islam, Modern Political Islam

\begin{abstract}
Abstrak
Hukum tentang pendirian partai politik menjadi diskusi yang menarik, artikel ini mencoba menganalisis berdasarkan literasi sejarah Islam dengan mengidentifikasi kelompok (hizb) yang menuntut estafet kepemimpinan sebagai bentuk artikulasi agar hak-hak mereka terwadahi, termasuk munculnya golongan Khawarij, Mu'tazilah dan Syi'ah yang diidentifikasi sebagai refleksi Islam politik klasik. Adapun refleksi Islam politik modern ditandai dengan agregasi kebutuhan kontemporer yang tidak bisa dipungkuri terhadap keharusan pendirian partai politik dengan melihat isuisu di Mesir dan Indonesia di era awal kemerdekaan. Perbedaan pandangan dikalangan cendekiawan serta ijma' ulama termasuk faktor dalam menentukan kesimpulan hukum mendirikan partai perspektif Islam.
\end{abstract}

Kata Kunci: Partai Politik, Islam Politik Klasik, Islam Politik Modern 


\section{PENDAHULUAN}

Penerapan hukum syariah dalam sebuah negara menjadi perdebatan sengit antara pemikir Islam. Wael B. Hallaq dalam bukunya "The Imposible State" menyatakan bahwa syariah tidak cocok dengan konsep sistem negara modern karena negara modern tidak didasari dengan nilai moralitas. Hallaq menguatkan argumennya melalui deskripsi tentang kebangkitan sejarah negara modern dengan membandingkan paradigmatik pemerintahan Islam. Ketikcocokan tersebut menurut Hallaq berdasarkan ciri-ciri kedaulatan negara modern, monopoli kekuatan, proses dominasi formasi yang serba subjektif dan abstraksi diskursifnya sebagai subjek yang universal dan abadi (Hallaq, 2013: 23-26). Berbeda dengan pandangan Khalid yang optimistik menilai apabih hukum syariah diterapkan dalam sebuah negara, sudah barang tentu akan menjamin setiap warga negara karena kedaulatan ada di tangan syara' sedangkan kekuasaan di tangan rakyat.

Alasan ini berdasarkan keunikan politik Islam dengan adanya prinsip keadilan, persamaan hak, kebebasan dan kesejahteraan yang dapat dirasakan oleh masyarakat (Ali, 2012: 51). Pemikiran tersebut didukung oleh pandangan Abdul Qadim yang menekankan peranan penguasa (stackholder) dalam mengatur sebuah negara modern perlu memberi jaminan agar prinsip-prinsip tersebut tercapai berdasarkan tujuan syariah (maqasid al-Syariah). Lebih lanjut Abdul Qadim menegaskan bahwa negara tidak akan mendapatkan suatu manfaat sekiranya hak-hak individu tidak terpenuhi. Hal ini karena dasar dan tujuan dari pendirian negara adalah agar setiap warga dapat menerapkan kehidupan Islam secara sempurna. Bagaimanapun, tujuan itu hanya bisa tercapai jika setiap warga negara dapat menikmati secara utuh semua hak mereka baik dalam berpolitik atau hak sebagai rakyat (Zallum, 2002: 41).

Dalam prinsip syariah terdapat dua aturan yang memberikan hakhak tersebut, yaitu Islam tidak memperbolehkan sebuah negara yang berdasarkan pengaruh atau penguasaan hanya pada seorang individu atau suatu pihak. Dengan kata lain, sebuah negara hendaklah berdasarkan persetujuan (social contract) dan kerjasama masyarakat, aturan diperintahkan dalam al-Qur'an disebut dengan pelaksanaan syura. (Surat Ali Imran: 15). Prinsip kedua ialah keterkaitan dengan tanggungjawab masyarakat untuk melaksanakan undang-undang syariah dalam segenap aspek kehidupan (Zaydan, 1983: 19), seperti yang disebutkan di dalam firman Allah yang berarti: "Ikutilah apa yang diturunkan kepadamu dari Tuhanmu". (Surat al-A'raf, hal. 252) Bagaimanapun masyarakat tidak boleh melaksanakan kedaulatannya secara langsung, oleh itu muncullah teori perwakilan yang akan dijelaskan dalam pembahsan teori pendekatan. 
Mekanisme berjalannya hak politik dalam masyarakat hanya akan terlaksana dengan adanya prinsip komunikasi yang intens antara masyarakat dan pemimpin mereka dengan wujudnya sebuah organisasi dan juga kepimpinan baik itu bersifat politik, ekonomi ataupun keagamaan. Keperluan adanya sebuah badan yang disebut organisasi adalah bertujuan agar kepentingan dan keinginan masyarakat (collective will) dapat direalisasikan. Dengan itu kewujudan sebuah organisasi merupakan pra-syarat atas perjuangan bersama. Keberadaan sebuah organisasi yang kokoh memerlukan peran beberapa orang pemimpin kaliber yang mampu untuk menguasai masa serta bertanggung jawab atas tindakan dan perilaku mereka. Dalam kontek organisasi yang lebih besar (negara) ada pentingnya melihat tentang model kepemimpinan pada zaman Islam klasik seperti zaman khalifah ar-Rasyidin yang memimpin selama lebih kurang 30 tahun $(632-660 \mathrm{M})$ hingga zaman pemerintahan Umar bin Abdul Aziz (717-720 M). Model ini agaknya yang dimaksud oleh Abdul Qadim tentang keberhasilan penerapan syariah dalam sebuah negara.

Sebagai contoh ketika terjadinya peristiwa musyawarah Tsaqifah Bani Sa'idah yang dipelori oleh para sahabat senior (seperti Umar dan Abu Bakar, Saad bin Ubadah) merupakan bentuk kontrol politik yang berlangsung secara damai, demokratis dan berdaulat sehingga aspirasi baik dari golongan kaum Muhajirin maupun Ansor dapat ditapung dengan baik. Secara tersirat proses penentuan pemimpin (khalifah) saat itu memunculkan aspirasi dari kedua kubu yaitu Muhajirin dan Ansar. Rasa fanatisme, kesukuan atau loyalitas tersebut terlihat mewarnai masing-masing kubu walaupun tidak sampai terjadi friksi atau perpecahan yang dicatat dalam sejarah dikarenakan peran dan andil dari senior para sahabat. Dari gambaran peritiwa tersebut menjadi memicu awal sebagai gap akademik dalam penulisan artikel ini, artinya dalam peristiwa itu mulai terlihat adanya kecenderungan terbentuknya kelompok yang mungkin bisa disebut sebagai hizb atau partai dalam istilah modern.

Dalam masyarakat yang majemuk, terbentuknya kelompok masyarakat kecil (hizb) tersebut tentu tidak dapat dihindari, bahkan tiaptiap kelompok atau hizb memiliki aspirasi untuk diperjuangkan sesuai dengan kepentingannya. Sebagai pengembangan dari gap akademik tersebut, penulis mencoba melihat dengan data, sejarah dan menganalisis berdasarkan refleksi Islam Politik Klasik (kelompok Islam seperti: Khawarij, Mu'tazilah dan Syi'ah) dan Islam politik modern (Kelompok Islam atau partai modern yang muncul setelah tahun 1945) tentang hukum dalam pendirian partai politik. 


\section{METODE PENDEKATAN}

Untuk memahami tentang hukum dalam pendirian partai politik menurut Islam, tulisan ini menggunakan metode pendekatan sejarah dengan memaparkan peristiwa dan kejadian Islam politik klasik dan Islam politik medern berdasarkan naskah, referensi dan manuskrip sejarah. Refleksi munculnya aliran di era awal Islam seperti kelompok Khawarij, Mu'tazilah ataupun Syi'ah menunjukkan adanya kelompok yang yang menuntut agar hak-hak dan kebebasan suara mereka dapat diakomodasikan oleh para pemegang kekuasaan pada zaman itu. Demikian juga peristiwa tentang munculnya kelompok yang menuntut agar estafet kepemimpinan dalam Islam dapat berjalan dengan sempurna sepeninggal Nabi, menunjukkan pentingnya badan atau institusi yang dapat mewadai hak-hak mereka.

Sehubungan pembahasan tentang hukum pendirian partai politik, tulisan ini juga didasarkan kepada pandangan ulama (sarjana) dan refleksi Islam politik modern dengan melihat maslahat hukum yang berlaku dalam dinamika kehidupan masyakarat. Selanjutnya sebagai hasil istimbath yaitu dengan mendiskripsikan, membandingkan berdasarkan data, maka diharapkan pada akhir tulisan ini dapat disimpulkan tentang hukum pendirian politik menurut perspektif Islam.

\section{PEMBAHASAN}

\section{Teori Partai Politik dan Perwakilan}

Konsep negara modern, partai politik, pemilihan umum (pemilu) dan parlemen merupakan elemen-elemen terpenting dalam bekerjanya sebuah sistem pemerintahan demokrasi. partai politik mewadahi pluralisme aspirasi dan kepentingan masyarakat dan pemilu menjadi arena kontestasi demokratis bagi partai politik dan kandidat dalam rangka memperoleh mandat politik publik. Selain itu, parlemen adalah lembaga perwakilan rakyat yang merumuskan kebijakan dan kemudian diimplementasikan oleh pemerintah dari hasil pemilu (Haris, 2014: vi)

Secara teoritis, lembaga perwakilan dimulai dari perkembangan masyarakat yang makin maju, pengelompokan masyarakat makin besar, dengan demikian diperlukan sebuah organisasi masyarakat yang dapat memonitor, melindungi dan mengatur jalannya sebuah organisasi (partai). Sosiolog Islam Ibnu Khaldun menyatakan bahwa adanya organisasi kemasyarakatan atau ijtima'i al-insani adalah sebuah keharusan. Pendapat ini kemudian diikuti oleh filosuf dan ahli hukum Islam (al-Hukama') dengan adagiumnya yang terkenal "al-Insanu madaniyyun bi ath-thaba" manusia bersifat politis menurut tabiatnya (Sulaiman, 2013: 15).

Munculnya konsepsi demokrasi perwakilan yang dicetuskan oleh Rosseau yaitu rakyat yang berdaulat dan kemudian mewakilkan kedaulatannya kepada suatu lembaga yaitu pemerintah. Pada 
perkembangannya, konsep lembaga perwakilan menjadi beragam sesuai dengan perkembangan sosial politik yang terjadi di masyarakat. Namun demikian, tugas dan wewenang dari lembaga perwakilan trersebut dapat dikelompokkan menjadi dua (Sulaiman, 2013: 21-22). Pertama, Sebagai perwakilan rakyat yang mengawasi jalannya pemerintahan yang dilakukan oleh pemegang kekuasaan eksekutif agar kekuasaan tidak dijalankan secara sewenang-wenang. Kedua, sebagai pemegang kekuasaan legislatif untuk menjalankan keinginan rakyat dan diinterprestasikan dalam Undang-Undang Dasar (supreme legislative body of some nations).

Berdasarkan pembagian lembaga perwakilan tersebut yang bersinergi dengan konsep Trias Politica yang diperkenalkan oleh Jhon Locke yang kemudian disempunakan oleh Montesquie. Sebagaimana pernyataannya yang dikutip oleh Harold J. Laski menyatakan bahwa: When the legislative and executive powers are united in the same persons or body, there can be no liberty, because apprehensions may arise lest the same monarch or senate should enact tyrannical laws, to enforce them in tyrannical manner... (Montesque dalam Harold J. Laski, 1938: 297).

Senada dengan hal tersebut, menurut Arend Lijphart, unsur dari suatu negara demokrasi adalah adanya perwakilan rakyat, karena rakyat tidak dapat memerintah atau mengartikulasikan kepentingannya secara sendiri-sendiri, karenanya harus diwakilkan. Sesuai dengan hal tersebut, lembaga perwakilan banyak dibentuk di negara-negara yang ada di dunia saat ini, sebagai perwujudan demokrasi atau kedaulatan rakyat (Lijphart, 2014: 17). Lembaga perwakilan di dalam masyarakat biasanya dibagi dalam 2 (dua) kategori. Kategori pertama, perwakilan politik (political representation) dan kategori kedua, perwakilan fungsional (fungtional representation) (Lijphart, 2014: 52). Kedua kategori tersebut menyangkut peran anggota parlemen sebagai trustee (wakil) dan perannya sebagai pengemban mandat perwakilan (representation) adalah konsep bahwa seseorang atau suatu kelompok mempunyai kemampuan dan kewajiban untuk berbicara dan bertindak atas nama suatu kelompok yang lebih besar.

\section{Kemelut Politik Dalam Islam}

Awal terjadinya kemelut politik dalam sejarah Islam adalah pada masa pemerintahan Utsman bin Affan, baliau merupakan seorang pemimpin sebuah pemerintahan yang berpusat di Madinah dan memiliki kekuasaan sangat luas sebagai penerus dari pemerintahan sebelumnya. Pengaruh kekuasaan ini sekaligus telah mendatangkan perubahan terhadap struktur negara dan juga persekitarannya. Dapat dikatakan bahawa dalam pemerintahan Utsman merupakan generasi kaum Muslim yang disifatkan sebagai generasi kuat beragama dan bertekat untuk 
menjadikan syariah sebagai undang-undang telah diganti dengan generasi baru yang dihasilkan atas penaklukan yang akhirnya mengarah kepada timbulnya prasangka kesukuan dan kebangsaan.

Sebagai akibat dari hal ini, setiap kelompok masyarakat Islam mulai instropeksi dan mawas diri terhadap keadaan mereka sendiri dalam mencari persamaan di antara sistem politik yang unggul di zaman khalifah sebelumnya, dengan membandingkan situasi yang terjadi pada zaman pemerintahan Utsman bin Affan. Oleh karena itu terdapat banyak perbedaan, akhirnya setiap kelompok dari masyarakat Islam pada waktu itu membentuk opini mereka sendiri tentang persoalan politik (Amin, 1969: 252), dan sebagian dari pandangan tersebut kemudian berubah menjadi sebagian dari pegangan partai-partai politik. Pandanganpandangan yang muncul di akhir pemerintahan Utsman didasarkan karena empat faktor yaitu berkaitan dengan permintaan untuk menyingkirkan gubernur-gubernur, seputar perdebatan tentang hak orang Quraisy dalam memegang jabatan khalifah dan gubernur, tentang statemen Abu Dzar tentang kebijakan keuangan dan konflik antara Ali bin Abi Talib dengan Mu'iwiyah bin Abi Sufyan (Masalah Tahkim).

Masalah pertama tentang permintaan untuk menyingkirkan gubernur-gubernur yang dilantik oleh khalifah telah dilakukan pertama kali di Kufah apabila rakyat meminta agar Utsman menyingkirkan alWalid bin Uqbah. Utsman menerima permintaan rakyat dan memecat alWalid. Bagaimanapun setelah itu rakyat Kufah turut menunjukkan rasa tidak puas hati mereka terhadap pengganti al-Walid, yaitu Said al-As dan meminta Utsman menggantikannya dengan gubernur baru itu Abu Musa al-'Asy'ari, seorang yang telah disingkirkan sebelumnya dari jabatan gubernur di Basrah dan khalifah sekali lagi mengikuti kehendak mereka. Akhirnya benih-benih masalah baru telah muncul bersamaan dengan model penggantian gubernur ini pada waktu pemerintahan Utsman, sehingga ini menjadi satu dilema di dalam masyarakat Islam saat itu.

Utsman telah mengambil sikap tegas tentang penyingkiran gubernur apabila rakyat tidak setuju terhadap keputusannya. Bagaimanapun urusan ini telah merebak begitu cepat sehingga berita itu telah digunakan untuk menyingkirkan gubernur-gubernur yang menjadi wakil khalifah dan kemudiannya mengarah kepada timbulnya satu permintaan yang justru untuk menyingkirkan Utsman sendiri. Akibatnya pendurhaka dan pemberontak telah mendesak khalifah Utsman untuk melepaskan jabatannya karena dituduh bahwa beliau telah melakukan beberapa kesalahan. Apabila Utsman enggan, mereka menyerang rumahnya dan membunuhnya ketika beliau sedang membaca Al-Qur'an. Dalam peristiwa ini baliau merupakan korban pertama dari kebijakan pemerintahannya sendiri. (S. El-Awa, 1991: 45). 
Isu selanjutnya yang menjadi kemelut politik adalah berhubungan dengan hak untuk menjadi khalifah dan jabatan-jabatan lain dalam pemerintahan supaya tidak hanya terbatas hanya untuk kaum Quraisy, yaitu suatu prinsip yang telah diterima umum sejak musyawarah Saqifah lagi. Hal ini telah menyebabkan munculnya pertentangan sengit di antara sebagian pembesar dan gubernurnya, Sa'id bin al-As di Kufah. Disebutkan dalam satu kejadian Gubernur Sa'id berkata kepada pembesar-pembesar negeri Kufah bahwa: "Kawasan ini adalah taman kaum Quraisy dan seorang dari pembesar negeri menjawab dengan marah sambil bertanya: Apakah kamu bermaksud bahwa kawasan yang dikaruniakan oleh Allah kepada kita melalui peperangan adalah suatu taman untuk kamu dan kaum kamu? "Urusan ini akhirnya telah sampai pada tahap yang berbahaya karena atas permintaan Sa'id bin al-As, Utsman telah mengusir mereka yang membantahnya dari Kufah kepada gubernurnya Mu'awiyah bin Abi Sufyan di Syam di mana mereka kemudian mengulangi penentangannya. Dalam pertemuan dengan Mu'awiyah perdebatan telah menjadi satu sindiran yang berat sebelah yaitu "kaum Quraisy bukannya golongan mayoritas atau terkuat semasa jahiliah sehingga menjadi ancaman kepada kami." (al-Jazri, (1956: 53). Ungkapan tersebut justru menunjukkan alamat bahwa ditingkat bawahan sekalipun telah muncul penentangan yang kuat dan dengan sendirinya peraturan politik sesungguhnya telah jatuh ke dalam masyarakat.

Pandangan lain yang juga ikut menyumbang munculnya kesukaran politik dalam masyarakat Islam pada waktu itu adalah prinsip seorang sahabat Rasulullah, Abu Dzar al-Ghifari berhubungan dengan aturan keuangan. Di antara aspek penting dalam pandangan Abu Dzar ialah: "Seseorang Islam tidak harus mempunyai kekayaan kecuali apa yang bisa menahannya untuk keperluan sehari semalam saja atau sesuatu untuk dibelanjakan di jalan Allah atau untuk menjanjikannya kepada orang yang membuat kebaikan" (al-Rayyis, 1969: 45-46).

Untuk memperkuat pandangannya beliau mengutip firman Allah yang artinya: "Mereka yang mengumpulkan emas dan perak yang tidak membelanjakannya mengikut jalan Allah, beri kabar kepada mereka tentang hukuman yang menyakitkan" (S. El-Awa, 1991: 47), Pendapat ini difahami seolah-olah jika harta belanja melebihi kebutuhan maka itu dikatakan bertentangan dengan nash Al-Qur'an. Dengan munculnya pandangan Abu Dzar, ini memicu perdebatan telah terjadi di antara beliau dengan Mu'awiyah. Abu Dzar berkata kepada Mu'awiyah: "Harta adalah kepunyaan Allah", dan Mu'awiyah mencegah Abu Dzar dari menyebut urusan itu dan memberitahunya, "Saya tidak mengatakan yang harta bukannya kepunyaan Allah, tetapi saya juga akan mengatakan itu adalah harta kaum Muslimin". Sikap ini menunjukkan satutanda kesabaran Mu'awiyah agartidak terjadi perselisihan dengan Abu Dzar berdasarkan pengetahuannya dalam Fikih 
dan kedudukan di kalangan sahabat-sahabat Rasulullah SWT (al-Arabi, $1375 \mathrm{H}:$ 73-76).

\section{Tahkim Konflik Antara Ali bin Abi Talib dengan Mu'awiyah.}

Peristiwa tahkim (penghakiman) dalam sejarah politik masyarakat dan negara Islam menjadi penting untuk memahami realitas sejarah politik negara Islam pada zaman awal, hal ini untuk melihat pengaruh terhadap negara Islam Madinah dalam memahami kejadian tersebut dengan gambaran yang jelas. Menyikapi peristiwa ini diantara langkah yang dilakukan adalah musyawarah yang digagas oleh Amr bin 'As dan Abu Musa al-Asy'ari untuk membicarakan masalah perselisihan yang terjadi antara Ali bin Abi Talib dengan Mu'awiyah bin Abi Sufyan. Kedua tokoh itu sepakat dalam pembicaraan mereka untuk memecat keduaduanya, yaitu Ali dan Mu'awiyah. (S. El-Awa, 1991: 52

Untuk mengetahui peritiwa ini secara objektif, diperlukan analisis secara mendalam terutama dalam tiga hal, pertama, sebab-sebab terjadinya konflik di antara Ali dan Mu'awiyah yang berakhir dengan peperangan. Kedua, posisi keduanya dilihat dari segi Undang-undang dan ketiga, karakter Abu Musa sebelum peristiwa tahkim terjadi.

Pertama, Konflik antara Ali dan Mu'awiyah. Konflik di antara mereka berdua adalah disebabkan karena pembunuhan terhadap Utsman bin Affan. Peristiwa ini juga telah mencetuskan pertentangan antara Ali dengan mereka yang memeranginya di dalam peperangan al-Jamal (Perang Unta). Setelah pembunuhan Utsman dan ikrar baiat kepada Ali bin Abi Talib dibuat, satu kelompokdari sahabat Rasulullah s.a.w yang terdiri dari Talhah, al-Zubair dan UmmulMukminin Aisyah binti Abu Bakr berpendapat bahwaAli harus disalahkan karena tidak menuntut bela atas kematian Utsman dan melakukan Qisos terhadap pembunuhpembunuhnya. Mu'awiyah juga setuju dengan pendapat ini dan akibatnya beliau enggan untuk berbaiat kepada khalifah Ali bin Abi Talib, ataupunmematuhi perintahnya di Damaskus. Sedangkan Ali merasa yakin bahwa baiat yang diikrarkan oleh umat Islam di Madinah adalah sah berdasarkan persetujuan kaum Muslimin yang hadir pada waktu itu. (al-Zahiri, 1964: 141).

Keengganan Mu'awiyah untuk baiat kepada adalah jelas, Ali menganggap bahwa dengan penyerangan kepadanya yang dilakukan oleh Mu'iwiyah dan rakyat Syria adalah dicap sebagai pemberontak. Bagaimanapun dilihat kedudukan Ali sebagai kepala negara melalui pelantikannya, beliau bertekad memaksa mereka supaya mematuhi dirinya sebagai khalifah yang sah. Dengan itu tercetuslah peperangan antara Ali dan Mu'awiyah. Mu'awiyah menentang Ali karena kesalahannya tidak menuntut bela atas kemangkatan Utsman serta tidak menghukum pembunuh-pembunuhnya. Mu'awiyah menginginkan agar 
urusan pembunuhan Utsman hendaklah diselesaikan terlebih dulu sebelum ikrar baiat kepada Ali sebagai khalifah. Menurut Alisikap itu dianggap satu penentangan terhadap kekuasaannya dan suatu pelanggaran terhadap baiat ummat Islam Madinah terhadap beliau, dan ini merupakan tindakan yang bisa dianggap sebagai pembangkang dan jika perlu harus diatasi dengan kekerasan seperti yang terkandung dalam surat al-Hujurat yang berarti: "Maka perangilah (golongan) yang berbuat zalim itu sehingga golongan itu kembali kepada perintah Allah". (Al-Qur' an al-Karim, al-Hujurat: 9)

Kedua, posisi Ali dan Mu'awiyah dari segi hukum. Seperti diketahui bahwa Mu'iwiyyah telah dilantik sebagai gubernur di Damaskus oleh Khalifah Umar bin Khattab hingga beliau wafat. Apabila Utsman mengambil posisi jabatan khalifah setelah kemangkatan Umar, baginda mengesahkan jabatan Mu'awiyah sebagai gubernur telah berakhir apabila Utsman dibunuh. Oleh sebab itu, walaupun Mu'awiyah berhenti menjadi pemerintah de jure (yang sah) di Damaskus, akan tetapi secara de facto beliau masih menguasai pemerintahan tersebut. (S. El-Awa, 1991: 55). Dengan tidak mau berbaiat kepada Ali dan menuntut agar penetapan Qisas terhadap pembunuh-pembunuh Utsman diprioritaskan maka Mu'awiyah dan pengikut-pengikutnya telah menjadi pembelot dan pemberontak yang menentang kekuasaan Ali (S. El-Awa, 1991: 56)

Ketiga, memahami Karakter Abu Musa al-Asy'ari, beliau adalah mantan gubernur yang telah dilantik ke beberapa wilayah pemerintahan Islam sejak zaman khalifah Umar bin al-Khattab. Di antara negeri-negeri di mana Abu Musa al-Asy'ari telah menjadi gubernur ialah Aden, Zabaed, Basrah dan Kufah yang dianggap sebagai tempat terakhir beliau bertugas sebagai gubernur pada zaman pemerintahan Utsman bin Affan. (S. ElAwa, 1991: 57). Ibn Hazm bahkan telah mendudukkan Abu Musa dalam kelompok pertengahan di kalangan ahli-ahli hukum sahabat Rasulullah dan beliau berkata tentangnya: "Pandangan undang-undang tiap-tiap mereka boleh dijadikan sebagai sebuah buku kecil". Beliau menyatakan sahabat-sahabat tersebut berjumlah lebih 160 orang berdasarkan pandangan undang-undang yang dikeluarkan oleh mereka: Abu Musa al-Asy'ari diletakkan di tempat yang ke 15" (al-Zahiri, 1957: 320).

Keputusan pendamai untuk merujuk perseteruan antara Ali dan Mu'awiyah kepada kelompok sahabat yang disenangi oleh Rasulullah s.a.w. sehingga baginda wafat adalah jelas merupakan hasil kesepakatan yang tidak dilaksanakan. Di sini sangat jelas bahwa peristiwa tahkim telah menyebabkan perpecahan di kalangan masyarakat Islam. Perpecahan ini menjurus kepada munculnya beberapa kelompok atau partai politik dalam istilah zaman ini. 


\section{Lahirnya Partai-partai Politik Pada Zaman Islam Klasik}

\section{Kelompok Khawarij}

Khawarij merupakan kelompok ekstrim pertama yang muncul di era awal Islam. Slogan yang didengungkan ialah: "Tidak ada peraturan lain kecuali dari Allah". Fanatisme dan kekakuan dalam memegang prinsip dengan slogan tersebut justru menimbulkan keributan dalam masyarakat Islam pada waktu itu. Walaupun dalam kelompok itu terbagi lebih dari dua puluh golongan, tetapi mereka menafsirkan slogan tersebut diintepretasikan menurut cara mereka sendiri. Di antara kontroversi radikal ini mereka tidak mengakui pebedaan pendapat yang datang darigolongan selain mereka. Segala sesuatu perbedaan pendapat dianggap menentang keputusan Allah ataupun tidak mempercayainya. Ruang untuk perbedaan pendapat yang diakui oleh Islam tidak masuk dalam alam fikiran mereka.

Khawarij menganggap dirinya berada di jalan yang benar dalam menegakkan perintah Allah.Setiap pihak yang memiliki perbedaan pendapat hingga mereka masing-masing saling mengklaim diri mereka benar bagi menegakkan perintah Allah. menyikapi Khawarij khalifah Ali bin Abi Talib sendiri telah mengkritik pendirian golongan ini melalui satu tanggapan yang beliau berikan terhadap jawaban teriakan golongan tersebut ketika di Masjid Madinah: "Tidak ada peraturan peraturan lain kecuali Allah", lalu Ali menjawab: "Itu adalah benar, tetapi itu telah digunakan untuk tujuan yang jahat. "Walaupun demikian sikap Ali masih dibilang lunak terhadap mereka. Kami akan menjamin anda tiga perkara: Kami tidak akan menghalang kamu dari memasuki masjid Allah untuk bersembahyang, kami tidak akan memulai serangan kepadamu atau enggan membantu kamu asalkan kamu bekerjasama dengan kami". Tujuan jahat yang dimaksud Ali terhadap golongan Khawarij adalah bersalah karena kafir (kekufuran) yang melegalkan penentangan mereka terhadapnya, hal ini memunculkan tindakantindakan buruk. Riwayat lain berkaitan dengan dialog di atas telah dikisahkan oleh sebagian pengikut Syi'ah: "Ali telah menjawab atas tuduhan mereka (golongan Khawarij) yang mengatakan: "Tidak ada peraturan lain kecuali dari Allah adalah: "Ya, tidak ada peraturan lain kecualidari Allah; tetapi mereka ini mengatakan yang tidak ada peraturan kecuali Allah, dan manusia mesti mempunyai pemimpin" (Imam al-Mawardi, 1976: 58).

Kantor pusat Khawarij yang ada di Nahrawan telah berhasil dibubarkan oleh Ali, akan tetapi kelompok ini justru semakin hari mereka menjadi semakin kuat. Mereka berani memberontak menentang negeri-negeri yang ada dibawah kekuasaan Bani Umayyah dan Abbasiyah. Golongan ini menjadi sumber masalah di dalam masyarakat Islam dalam rentang waktu yang panjang. Walaupun 
kelompok Khawarij ini terpecah kepada dua puluh kelompok dan hanya setuju tentang dua prinsip pokok. Pertama mereka menerima legalitas kepemimpinan $\mathrm{Abu} \mathrm{Bakr}$, Umar dan separuh pertama dari pemerintahan Utsman, tetapi menolak bagian akhir kekuasannya. Mereka juga menerima pemerintahan Ali sehingga terjadi peristiwa tahkim. Setelah itu mereka bukan saja menolak Ali, bahkan juga mengutuknya dan menganggap Ali sebagai orang yang ingkar kepada Allah.

Kedua, berkaitan dengan keyakinan mereka tentang pentingnya menentang perintah yang tidak adil, juga kekayaan yang akan dianggap sebagai kewajiban keagamaan (fard) dan tidak wajar sekiranya dilalaikan. Bagi merakajumlah atau kekuatan bukanlah syarat utama untuktidak melawan kezaliman menurut mereka. Memperjuangkan keadaan yang tidak adil adalah penting selama masih ada kemauan atau keupayaan mereka akan terus melakukan pemberontakan walaupun perorangan tanpa memperhitungkan target capaian yang dimaksud (al-Baghdadi, 1968: 55-056).

\section{Kelompok Syi'ah}

Seperti yang diketahui dalam kasus pertengkaran di antara Ali dan Mu'awiyah, setelah kedua pendamai mengumumkan keputusan mereka, kelompok Syi'ah menyatakan dukungan mereka terhadap Ali dengan berkata "Kami berhutang kepada anda baiat yang kedua. Kami berikrar untuk setia kepada sekutu-sekutu anda, dan kami akan menentang musuh-musuh anda" (al-Afghani, 969: 101). Bagaimanapun munculnya golongan Syi'ah tidak bisa dikatakan karena adanya baiat. Bahkan dua faktor lain juga memainkan peranan penting dalam mengidentifikasi kebangkitan mereka. Pertama adalah faktor yang melibatkan keadaan yang dikaitkan dengan kejadian-kejadian peristiwa sejarah yang membantu menambah perasaan setia dan kecintaan terhadap Ali dan keluarganya. Ini juga membawa akibat tragis dalam jihad yang dilakukan oleh Ali sepanjang pemerintahannya walaupun berakhir dengan pembunuhan terhadap dirinya oleh golongan Khawarij. Kedua, berkaitan dengan implikasi sosial, ekonomi dan kebudayaan dengan penyertaan mualaf-mualaf yang meminta nasihat dariulama Syi'ah dalam membentuk masyarakat Islam. Antara implikasi yang paling penting adalah dukungan mereka terhadap pemikiran Syi'ah yang memerlukan uraian panjang. (Ibn Athir, 1956: Jil 3; 134).

Tindakan kelompok Khawarij yang meninggalkan Ali bin Abi Talib bersama satu kelompok tentara yang setia kepadanya memicu munculnya kelompok Syi'ah. Golongan ini mempunyai konsep politik yang tersendiri, yaitu ketaatan terhadap Ahlu Bait (keluarga 
Rasulullah), dogma ini juga pada dasarnya berhubungan dengan urusan suara hati atau perasaan, yaitu kecintaan terhadap Ahlu Bait. Oleh karena itu agar dikenal dan bisa diterima oleh masyarakat luas, propaganda perjuangan Syi'ah telah menghabiskan waktu yang lama melalui evolusi sejarah hingga akhirnya keberadaan mereka juga mendapat pengakuan kelompok Khawarij. Walaupun Syi'ah telah terbagi menjadi banyak golongan dan yang paling penting adalah munculnya aliran Kisaniyyah, kemudian Imamiyah, Zaidiyah dan Ismailiyah. Walaupun golongan ini berbeda dalam memegang prinsip politik, undang-undang dan asal mereka, bagaimanapun mereka semua sepakat berpendapat tentang kemuliaan Ali, hanya untuk jabatan memangku khalifah dan penyimpan hak tersebut kepada keturunannya yang mesti dipindahkan melalui pelantikan dari imam kepada penggantinya (Amin, 1969: 269-278)

.Golongan Zaidiyah berbeda terhadap dua hal yang yang terakhir. Menurut mereka, tidak perlu ada pelantikan untuk jabatan imam yang akan jatuh kepada siapapun dari keturunan Fatimah dengan syarat pemimpin harus yang berpengetahuan, tabah, rendah hati, taat dan mempunyai kemampuan untuk memperjuangkan haknya. Lantaran itu menurut mereka pemimpin adalah aktif bukan pasif. Berbeda dengan golongan Imamiyah,mereka mempercayai imam tersembunyi yang akan muncul kemudian hari dan memperjuangkan keadilan di dunia yang sekarang ini dipenuhi dengan ketidakadilan. Kepercayaan ini berlawanan dengan golongan Zaidiyah. Mereka tidak mempercayai keunggulan dan keistimewan imam-imam tidak seperti Imamiyah, atas dasar prinsip ini, ijtihad menurut Zaidiyah adalah dibolehkan sehinnga memberikan dampak terhadap banyaknya penulisan dan karya dalam perundangan.

\section{Kelompok Mu'tazilah}

Golongan Mu'tazilah didirikan oleh Wasil bin Ata' dan Amru bin Ubaid pada awal abad kedua hijrah sebagai hasil dari pengunduran diri mereka dari kelompok gurunya Hasan al-Basri yang mengajarkan bahwa orang yang melakukan kesalahan besar adalah fasiq (berdosa), pendapat tersebut disetujui oleh golongan mayoritas masyarakat, namun ditolak oleh golongan Khawarij. Mereka mengatakan bahwa orang yang demikian adalah kafir walaupun definisi mereka terhadap kata kafir berbeda.

Golongan Abadiyah mendefinisikan kufur sebagai tidak bersyukur kepada Allah, sedangkan lainnya mendefinisikan sebagai syirik (menyekutukan Allah). Posisi ini memisahkan seseorang darilingkungan iman tetapi tidak menggolongkan ke dalam golongan kufr atau munafik. Dengan adanya perbedaan ini mereka memisahkan dari gurunya Hasan al-Basri yang berbeda pendapat dengan mereka 
dan memanggil dengan julukan Mu'tazilah (yang terpisah) (al-Zahiri, 1964: 11). Golongan Mu'tazilah kemudian mengembangkan beberapa prinsip tertentu yang menurutnya iman terjadi dengan hanya mengikuti dasar berikut: Teori pengantara antara dua keadaan yaitu kebenaran janji-janji Allah (Syurga) dan ancaman (Neraka), dan menyuruh berbuat benar dan melarang berbuat salah. (Abd al-Qadir al-Baghdadi, 1968: 83-101).

Secara terperinci bisa dikatakan bahwa sebab yang mengarah kepada pembicaraan prinsip pertama adalah semata-mata karenaadanya motif politik, yaitu untuk membentuk suatu pembatas untuk mengukur perbedaan dalam hal-hal politik, terutama berhubungan dengan peperangan dan pertentangan yang terjadi di kalangan para sahabat. Masalah inilah yang menyebabkan kelompokkelompok Muslimin memiliki pendapat yang berbeda. Contohnya golongan Khawarij menganggap seseorang sebagai kafir jika tidak mengikut doktrin mereka, namun golongan mayoritas Muslimin yang dikenal sebagai Ahlu Sunnah secara prinsipnya tidak menganggap siapapun yang melakukan dosa dari kalangan Ahlu Qiblah (orang menghadap Ka'bah) dihukum sebagai kafir. Sebaliknya golongan Mu'tazilah menganggap seseorang yang melakukan dosa besar adalah terletak pada pertengahan antara iman dan kufur.

Golongan Mu'tazilah mengukur segala perbuatan dan kata-kata para sahabat mengikuti standar ini bahkan mereka menjelekkan dan menyakitkan hati yang lain. Mereka mengatakan, sedangkan para sahabat sendiri tidak berhenti dari menunjukkan kesalahan sendiri. Menurut kelompok Mu'tazilah, keberanian seperti itu kurang mendapat respon dari sahabat. Ini sebabnya mengapa golongan mayoritas kaum Muslimin menolak Mu'tazilah yang dianggapnya sebagai kelompok yang menyimpang dari agama dan sunnah Rasulullah s.a.w.. Seperti ketika memutuskan apakah kelompok itu fasiq (berdosa) atau tidak, hal itu dapat dicermati dalam kasus Perang Jamal, satu kelompok berafiliasi kepada Ali seperti Talhah, al-Zubair, sedangkan Aisyah bersama dengan kelompok lainnya. Pandangan mereka yang paling berbahaya adalah berdasarkan doktrin seperti konsep mereka dalam menilai satu golongan adalah fasiq (berdosa), tetapi karena tidak bisa dibuktikan dengan jelas pihak manakah itu, maka golongan Mu'tazilah memutuskan fasiq (berdosa) (Al-Qadi Abd al-Jabbar bin Ahmad, 1975: 128-148)

Golongan Mu'tazilah tidak setuju dengan golongan Khawarij yang menganggap pemberontakan menentang pemimpin yang tidak adil sebagai kewajiban individu tanpa mempertimbangkan akibatnya. Berdasarkan keyakinan inilah golongan Mu'tazilah memberontak dan menentang al-Walid bin Yazid bin Abd al-Malik ketika beliau 
melakukan kedholiman serta gratifikasi hingga akhirnya beliau digulingkan. Kemudian terhadap sepupunya Yazid bin al-Walid, seorang yang adil dan warak yang menggantikannya dianggap sebagai syarat bahwa pemimpin harus memiliki keimanan. (Abd al-Qadir alBaghdadi, 1968: 104).

\section{Pendirian Partai Politik Perspektif Islam: Refleksi Partai Modern}

Untuk mendapatkan pandangan yang jelas tentang hukum Islam dalam pendirian partai politik, perlu dirujuk terlebih dulu terutama referensi atau nash yang disebutkan oleh Al-Qur'an ataupun Hadis berkenaan dengan penyebutan "partai politik". Perkataan atau istilah yang menyamai perkataan 'partai' di dalam bahasa Arab modern ialah perkataan 'al-Hizb'. Nash al-Qur' an menyebut: "Kullu hizbim bima ladayhim farihun" yang maksudnya: "tiap-tiap golongan merasa bangga dengan apa yang ada pada sisi mereka" (Surat Al-Rum: 32). Demikian juga dalam surat alRum: "Minal ladhina farraqu dinahum wa kanu shiya'an kullu hizbin bima ladayhim farihun" yang berarti: "tiap-tiap golongan merasa bangga dengan apa yang ada pada golongan mereka" (Surat Al-Rum: 32). Di dalam hadis Rasulullah juga kita temui sebuah perkataan berkenaan dengan tema ini, misalnya sabdanya yang berbunyi: "Taftariqu ummati 'ala thalath wa sab' in firqatan" artinya: "Umatku (masyarakat Islam) akan berpecah kepada tujuh puluh tiga golongan" (Abd al-Qadir al-Baghdadi, 1968: 55-56).

Penggunaan kata al-Hizb di dalam ayat di atas adalah menunjuk kepada orang-orang yang menggunakan nama Rasulullah dalam usahanya mewujudkan perpecahan di kalangan kaum Muslimin dengan menyebarkan mazhab yang bersifat teologi yang berbeda-beda seperti yang telah disebutkan sebelum ini, dan setiap kelompok mazhab tersebut mempopulerkan pegangan mereka dan bukannya mengajarkan ajaran Islam yang berpandukan kepada ajaran tauhid. Bahkan dalam keadaan tertentu al-Qur'an juga telah menggunakan perkataan "al-Hizb" dan perkataan "shiya'an" dengan merujuk kepada orang-orang yang menentang Rasulullah s.a.w seperti orang Yahudi dan juga orang kafir seperti yang terjadi dalam perang Khandaq. Kedua perkataan tersebut tidak ditemukan pernah digunakan dengan merujuk kepada perkataan 'partai' yang dimaksud di dalam ilmu politik di zaman modern.

Sebagian sarjana Islam seperti Abu al-Ala al-Mawdadi dan juga alWasfi telah menggunakan ayat-ayat di atas sebagai bukti dalam memperkokoh alasan mereka bahwa Islam melarang pendirian partai politik apa pun itu bentuknya. Misalnya Abu al-A'la al-Maududi berkata: "Sebenarnya karena kamu menganggap diri kamu hanya sebagai warganegara sebuah negara bangsa dan melupakan diri kamu sebagai anggota partai sejagat dengan tujuan menjadikan ideologi partai tersebut yang dominan. Dengan itu selama kamu tidak dapat mengembangkan 
konsep yang jelas tentang politik maka kamu tidak berhasil" (Abd alQadir al-Baghdadi, 1968: 4).

Perlu diperhatikan kembali bahwa pernyataan Maududi di atas tidak menunjukkan penggunaan perkataan 'partai politik' dalam konteks yang digunakan pada zaman modern ini. Sebaliknya Maududi menggunakan perkataan 'partai' yang memberi arti sebagai 'masyarakat Islam' (the Islamic society) yang mewakili 'partai Allah' (Hizb Allah) untuk menentang partai Barat. Seorang sarjana Timur Tengah, al-Wasfi berkata: "Di antara pengaruh yang paling terlihat sebagai nilai dari pengintegrasian demokrasi dengan Islam adalah pendirian partai politik. Ini adalah satu penghinaan kepada Islam, karena hal itu bisa membawa perpecahan dan hakekatnya bertentangan dengan Islam." (Abd al-Qadir al-Baghdadi, 1968: 4).

Pandangan kedua tokoh baik Maududi ataupun al-Wasfi telah menganggap partai politik sebagai satu instrumen perpecahan dan konflik dan bukan satu hal yang bisa membawa kepada kestabilan dan pembangunan suatu negara. Pendapat kedua tokoh tersebut adalah sukar untuk bisa diterima, ini karena Islam sendiri memberikan hak serta kebebasan untuk mengeluarkan pendapat, di samping itu Islam juga menganggap bahwa perbedaan pendapat di kalangan individu adalah sesuatu yang bersifat manusiawi, bahkan kadang-kadang perbedaan itu justru bisa membuka jalan untuk mendapat sesuatu kebenaran dan membuang kesalahan; dengan itu merupakan satu faktor yang membangun dan bukan sebagai alat perusak. Untuk memperkuat pendapat ini baik dikutip apa yang dikatakan oleh Imam Ahmad Ibn Hanbal kepada Imam seperti berikut: "Aku telah berdosa kepada Imam Syafi'i selama empat puluh tahun di dalam sembahyang, dan Imam Syafi'i juga berkata mengenai Imam Malik bahwa dalam hal yang berkaitan dengan keilmuan Imam Malik dikategorikan sebagai seorang ilmuwan yang terbaik, yang tidak ada tandingannya" (L Thaib, 1994: 79).

Sebagai legitimasi dalam memberikan pandangan yang cerdas berkaitan dengan pendirian partai politik adalah perlu untuk memahami bahwa prinsip yang mendukung pendirian partai politik di dalam Islam bukanlah dengan tujuan untuk mendukung munculnya kelas-kelas dalam masyarakat Islam, sebaliknya itu hanya merupakan satu ungkapan yang menginginkan bahwa partai politik itu akan dapat membuat agenda pembangunan dan kemajuan untuk sebuah negara sesuai dengan semangat syariat Islam itu sendiri, selain itu partai politik juga dapat memperkuat nilai persatuan masyarakat melalui pembentukan mekanisme dalam demokrasi (Natsir, 2001: 199). Pernyataan Natsir diperkuat oleh Asaf ketika berbicara tentang fungsi partai dan perlindungan hak individu dalam negara: "Legitimasi partai politik hanya bisa berfungsi di bawah struktur sistem pemerintahan Islam agar hak-hak setiap 
individu dilindungi", bahkan menurutrnya hal ini justru akan dapat mewujudkan mekanisme yang bisa menjaga penyalahgunaan kuasa pada level para pejabat negara seperti dibentuknya Islamic Republic Party setelah berhasilnya revolusi rakyat Iran. (Hussain, 1985: 80).

Mencermati pendapat tersebut, dengan melihat fakta tentang pendirian partai politik serta adanya maslahat di dalam sistem politik Islam, maka hal tersebut bisa dikatakan sesuai dengan kategori hukum yang diperbolehkan (mubah) perspektif Islam, (Khurshid Ahmad (1983: 10), bahkan lebih lunak lagi partai itu bisa didirikan sesuai dengan kepentingan masyarakat. Peristiwa ini dapat dirujuk kepada sejarah awal Islam sebagai bukti autentik adanya pembicaraan di Saqifah Bani Saidah berhubungan dengan isu pelantikan kepala negara (khalifah) setelah wafatnya Rasulullah SAW merupakan petunjuk yang jelas bahwa golongan Muhajirin dan Ansar berdiskusi tentang hak-hak mereka untuk memimpin telah diakui sebagai golongan politik (partai politik). Selain itu di dalam sebuah perlembagaan Islam yang diusulkan oleh al-Azhar dinyatakan bahwa diantara ciri-ciri negara Islam adalah memperbolehkan dan memberikan kebebasan kepada kelompok atau sebagian masyarakat untuk mewujudkan partai politik. (Al-Azhar, 1951). Pernyataan ini juga diperkuat dalam deklarasi tentang hak asasi manusia dikatakan bahwa Islam tidak melarang pendirian partai politik. (The Islamic Council of Europe, 1985).

Sebagai refleksi terhadap pandangan Islam politik modern tentang hukum pendirian partai politik dalam Islam, perlu dicermati kembali peranan al-Azhar sebagai sebuah institusi besar di Mesir telah memberikan rekomendasi bolehnya mendirikan partai politik, satu sisi pandangan tersebut sejalan dengan apa yang dikatakan oleh pemimpin Ikhwanul Muslimin yang mengambil andil besar dalam kemerdekaan Mesir. Dalam melihat sistem parti politik yang berlaku di Mesir al-Banna telah mengkritisi hal-hal yang sebenarnya merupakan politik adu domba yang dilakukan oleh penjajah asing agar abadi dapat bercokol di bumi Mesir. Namun dengan melihat keadaan ketika itu, pembolehan pendirian partai politik menjadi satu keharusan bagi jalannya demokrasi walaupun dengan syarat yang ketat. (Susanto, 2013: 76).

Menyikapi keadaan di Mesir, Ruslan mengungkapkan pandangan al-Banna bahwa pembentukan partai-partai minoritas menurutnya tidak memiliki alasan apa pun selain hanya untuk mendapat kekuasaan dan uang. Hal ini terbukti bahawa wujudnya multi parti dalam percaturan politik pada waktu tidak memiliki agenda yang jelas yang tidak mengarah kepada kemaslahatan masyarakat dan negara. (Ruslan, 2000: 44). Pandangan ini apabila diteliti ada benarnya, karena model ini sudah menjadi suatu tradisi dalam kehidupan politik seperti kebiasaan gratifikasi, berbuat curang dalam pemilu bahkan raja atau elit politik juga 
terlibat dalam pengebirian konstitusi dengan memanfaatkan jabatan politik. Dalam kenyataannya, konstelasi perebutan kekuasaan yang dilakukan oleh partai politik antara tahun 1922-1952 menunjukkan bahwa pada hakikatnya pemerintah mengalami unstabil politic, sebagaimana disebut Ruslan (The Islamic Council of Europe, 1985).

Apa yang menjadi perbedaan pandangan dalam menyikapi fenomena tersebut, bahwa Al-Banna sepakat boleh mendirikan single party namun tidak sepakat adanya multi partai yang berkembang di Mesir. Ijtihad Hasan al-Banna tersebut menjadi sesuatu yang wajar, meskipun pada akhirnya disalah tafsirkan oleh penguasa Gamal Abd Nasr dengan kejadian revolusi 23 Juli untuk mendapat kuasa secara diktator. Alasan ini didasarkan bahwa multi partai pada waktu itu merupakan satu penyebab di antara sebab-sebab lain yang mengarah kepada perselisihan dan perpecahan. Disamping itu keadaan Mesir adalah belum merdeka dan berada di bawah kaki penjajah, secara tidak langsung apa yang dimaukan oleh mereka adalah justru dengan membentuk multi parti agar kekuatan bangsa bisa diporak-porandakan (Mahmud, 1997: 108).

Pengalaman proses pendirian partai politik di atas juga terefleksikan di Indonesia pada era awal kemerdekaan. Refleksi pendirian partai memicu semangat rakyat dengan maraknya partai baru yang mendaftar dari masyarakat secara umum. Hal ini berdasarkan setelah keluarnya keputusan pemerintah tertanggal 3 November 1945 tentang anjuran pendirian partai yang ditanda tangani wakil presiden Hatta: "Berhubung dengan usul Badan Pekerdja Komite Nasional Pusat kepada Pemerintah supaja diberikan kesempatan kepada rakyat seluas-luasnya untuk mendirikan partai-partai politik, dengan restriksi, bahwa parai-partai itu hendaknja memperkuat perdjuangan kita mempertahankan kemerdekaan dan mendjamin keamanan masjarakat, pemerintah menegaskan pendirianja jang telah diambil beberapa waktu jang lalu bahwa:a. pemerintahmenjukai timbulja partaipartai politik karena dengan adanja partai-partai baru itulah dapat dipimpin ke jalan yang teratursegala aliran paham jang ada dalam masyarakat. b. pemerintah berharap supaja partai-partai itu telah tersusun sebelum dilangsungkannya pemilihan anggauta badan-badan Perwakilan Rakyat pada bulan Djanuari 1946" (Fatkhurrahman, 2010: 89-90). Pasca turunnya pemberitaan pemerintah tersebut, maka saling bermunculan partai-partai politik di Indonesia bagaikan jamur di musim hujan. (Lutfi., et all., 2015: 59). Berdasarkan refleksi dan pandangan tentang pendirian partai politik, dinamika ini menjadi satu kewajaran dan keharusan dalam sebuah negara selama pendiriannya memberikan manfaat dan maslahat untuk bersama. (Noor, 2006: 76). 


\section{SIMPULAN}

Dalam sejarah Islam klasik telah muncul kelompok politik seperti yang telah dijelaskan dalam pembahasan. Penyebutan golongan ini diidentifikasi dengan istilah hizb dengan merujuk kepada nash al-Qur'an maupun hadis atau disebut partai dalam istilah modern. Golongan atau kelompok tersebut menuntut agar hak-hak mereka terwadahi dalam pemerintahan, hal ini merupakan refleksi dari Islam politik ditandai dengan peristiwa Saqifah Bani Saidah ketika musyawarah tentang pemilihan estafet kepemimpinan. Demikian juga munculnya sekte aliran seperti Khawarij, Syi'ah dan Mu'tazilah dapat dikategorikan sebagai kelompok atau disebut sebagai hizb (partai), dimana kemunculan hizb ini sebagai refleksi dan reaksi dalam dinamika kehidupan masyarakat yang tidak bisa dipungkiri meskipun dalam memahami kontek peristiwa tersebut, sebagian sarjana bersikukuh tidak sependapat tentang pendirian partai dan dikatakan tidak sesuai dengan hukum Islam. Adapun refleksi Islam politik di era modern berdasarkan kebutuhan kontemporer serta merujuk kepada pemahaman nash tentang pendirian partai, maka hal itu adalah diperbolehkan (mubah). Berdasarkan kedua refleksi tersebut baik diwakili oleh Islam politik klasik ataupun Islam politik modern, maka pendirian partai politik menjadi satu keharusan dengan tujuan untuk mencapai kesatuan masyarakat dari keterpecah-belahan menuju masyarakat yang adil dan sejahtera.

\section{DAFTAR PUSTAKA}

Al-Qur' an al-Karim

Sunan Abi Daud

Abd al-Karim Zaydan. Role of State and Individual Islam, Delhi: Hindustan Publication, 1983.

Abd al-Razzaq bin Hanunam al-San'ani. al-Mu.sanna, Cairo: Mukhtar alIslami, 1976.

Abdul Qadim Zallum. Sistem Pemerintahan Islam, Bangil: Al-Izzah, 2002.

Abi Bakr bin al-Arabi. Tarikh al-Tabari, Cairo: Matba'ah Bab, jil. 5, $1375 \mathrm{H}$.

Abu Bakr bin al-Arabi. Al-Awasim min al-Qawasim, Beirut: Dar al-Fikr, 1965.

Ahmad Amin. Fajr al-Islam, Beirut: Dar al-Fikr, 1969.

Ali Abdul Halim Mahmud. Wasail Al-Tarbiyyah 'IndaAl-Ikhwan AlMuslimun Dirasah Tahliliyyah Tarikhiyyah, Kaherah: Dar alTawzi' wa An-Nashr Al-Islamiy.Al-Azhar (1951), The Constitution for an Islamic State, Cairo: Higher Research Council of al-Azhar. 
Al-Qadi Abd al-Jabbar bin Ahmad. Sharh Usul al-Khamsa. Cairo: Matba'ah Bab al-Khalabi, 1975.

Arend Lijphart sebagaimana dikutip oleh Efriza. Studi Parlemen (Sejarah, Konsep, dan Lanskap Politik). Malang: Penerbit Setara Press, 2014.

Asaf Hussain. Revolution and Counter Revolution. London: Frances Printer Publisher. Lihat juga Lukman Thaib, Political System of Islam, 1985.

Deliar Noor. Partai Islam di Pentas Nasional. Jakarta: Gema Insani Press, 2006.

Fatkhurrahman. Pembubaran Partai Politik di indonesia. Malang: Setara Press, 2010.

Hasan al-Banna, Ila Maqaami Shahibi al-Jalalaj al-Malik Faruq al-Awwal, Ibn Qutaybah. Al-Imamah wa al-Siyasahah. Cairo: Matba'ah Bab, 1967.

Imam al-Mawardi. Al-Ahkam al-Sulthaniyyah. Cairo: Maktabah al-Halabi, 1976.

Jalal al-Din al-Sayuti. al-Itqan fi Ulum al-Qur'an. Cairo: Matba'ah Bab alHalabi), jil. 1, 1951.

Khalid Ali Muhammad Ali. An-Nidzam Al-Siyasi fi al-Islam. Riyadh: Maktabah al-Rasyad, 2012.

Khurshid Ahmad. Proportional Representation and the Revival of Democratic Process in Pakistan, Islamabad: Institute of Policy Studies, 1983.

King Faisal Sulaiman. Sistem Bikameral dalam Spektrum Lembaga Parlemen Indonesia. Yogyakarta: UII Press, 2013.

Lukman Thaib. Political System of Islam, Kuala Lumpur: Penerbit Amal, 1994.

Majalah al-Nazir Tahun 1, no. 3 Rabiulakhir 1357 h. 4 dalam Utsman Abdul Mu'iz Ruslan, 2000.

Montesque dalam Harold J. Laski. A Grammer Of Politics. London: GeorgeAllen and Unwin Ltd, 1938.

Muhammad Diya' al-Din al-Rayyis (1969), Muhammad Diya' al-Din alRayyis. Al-Nazariyyah al-Siyasiyyah al-Islamiyyah. Cairo: Dar alMa'arif, 1969.

Muhammad S. El-Awa. Sistem Politik Negara Islam. Kuala Lumpur: Dewan Bahasa dan Pustaka, 1991.

Nu'man Ahmad al-Khatib. Islamic Thought and Political Parties. di dalam:Islamic Order Quarterly, jil. 10, no. 1, 1988.

Ruslan, Uthman Abdul Mu'iz (1990), Al-Tarbiyah As-Siyasiyyah 'Inda Jama'ah Al-Ikhwan Al-Muslimin, fi Fatrah min 1928 ila 1954 fi 
Misr, Dirasah Tahliliyyah Taqwiniyah. Dar at-Tauzi' wa at-Tiba'ah al-Islamiyah

Seminar Pemikiran Mohammad Natsir, pada tanggal 18 April 1983, Dewan Besar Pusat Matrikulasi UII, anjuran Angkatan Belia Islam (ABIM)

Syamsudin Haris. Partai Pemilu dan Parlemen. Jakarta: Pustaka Obor, 2014.

The Islamic Council of Europe. The Declaration of Universal Islamic Human Rights. London: The Islamic Council of Europe, 1985.

Wael B. Hallaq (2013), The Impossible State: Islam, Politics and Modernity's Moral Predicament, New York: Columbia University Press.

Yusuf al-Qaradhawi. al-Tarbiyyah al-Siyasiyyah 'Inda al-Imam Hasan alBanna. Cairo: Maktabah Wahbah, 2007. 